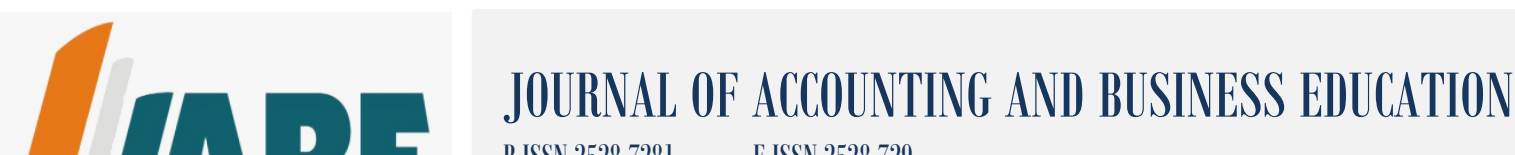 P-ISSN 2528-7281 E-ISSN 2528-729 \\ E-mail: jabe.journal@um.ac.id \\ http://journal2.um.ac.id/index.php/jabe/
}

\section{Individualized Excel-Based Exams to Prevent Students from Cheating}

\author{
Ani Wilujeng Suryani \\ Accounting Department, Faculty of Economics, Universitas Negeri Malang, Indonesia \\ email: ani.suryani@um.ac.id
}

DOI: http://dx.doi.org/10.26675/jabe.v5i1.14367

\begin{abstract}
The COVID-19 pandemic has brought a disruption to education, especially on how courses are delivered in higher education. Higher education providers are forced to go online, without considering the availability of IT infrastructure and capability of lecturers in delivering online courses. Since online learning is perceived as an opportunity for academic integrity breaches, academicians need to ensure that the learning processes prevent students from cheating activities, especially during the exams. This paper presents an innovative approach in delivering online, Excel-based exams which enable the lecturers to develop individualized exam questions. The accounting method and/or policy, as well as the accounting figures in the exams are automatically set based on the students' identification numbers. This program also allows automatic scorings for such exams. Based on the students' perceptions collected from the online survey, this type of exam was not considered complicated and somewhat reduced the cheating opportunities. Hence, it is suggested to use these individualized Excel-based exams in the future online exams to increase the exam's scoring objectivity and reliability scoring.
\end{abstract}

Keywords: excel-based exam, automatic scoring, accounting exam, individualized exam, accounting

\section{INTRODUCTION}

The Covid-19 outbreak with its massive challenges for human life brings disruptions which have never been predicted before. About 186 countries are affected, and one way to prevent further damage is by closing workplaces, shopping malls, and even schools/universities. Hence, like it or not, academicians are forced to adapt with the new ways of teaching through online learning. Consequently, teachers and lecturers should adopt the online flipping learning which combines the synchronous and/or asynchronous methods. These are expected creating flexibility and enjoyable learning experiences for students. However, some academicians are not ready to move their classes from offline into online learning environment. They merely change their classes from offline to online meetings via Zoom or any other video conference devices and in fact, this is a backward in education where the teacher-centered mode is re-used.

An accounting class is generally large. Hence, when it comes to exams, not only designing (Ashworth, Bannister, and Thorne, 1997; Doran et al., 2011) but also scoring the paper-based exams bring pain to the lecturers (Bertheussen, 2014). For this reason, it is suggested to use an innovative way, such as using computer-aided assessment to reduce the workloads (Evans, 2013; Gikandi, Morrow, and Davis, 2011; Marriott and Lau, 2008). Although an accounting exam can be conducted online, many prefer to have a traditional type of hands-on exam for the security and surveillance issues (Rogers, 2006; Sindre and Vegendla, 2015) to minimize the students' cheating activities during the exam. It is admitted by the 
students that cheating in an online exam is much easier (King, Guyette, and Piotrowski, 2009) unless the exam is well designed (Harmon, Lambrinos, and Buffolino, 2010).

During the pandemic, exams must be given online since conducting exams in offline classes are strictly prohibited by the law. In this online environment, lecturers must be highly creative in designing an individualized exam (Blayney and Freeman 2008; Nnadi, 2003) that no rooms for students to collude (Nnadi and Rosser, 2014). This paper aims at explaining an innovative approach possibly developed by the accounting lecturers to create the individualized excel-based exams to maintain the online exam quality and minimize the academic integrity breaches.

In the following sections, previous studies on online learning are presented, and exam designs are described. This also consists of problems, solutions, and scoring generating techniques. Next, students' feedbacks collected from surveys are presented. Conclusion and suggestions for future research are provided in the last section.

\section{LITERATURE REVIEW}

Online learning is actually not a new concept, as massive open online courses have been introduced a decade ago, allowing distance education. A good online learning should support the learner-centered approach to enable the students to interact with the others; and digest information as active learners who can logically adapt the knowledge transfer (Bento and Schuster, 2003). This online learning is more flexible than the traditional one (Herliandry et al., 2020), where teaching and learning activities may be performed anytime and anywhere (Dewi, 2020) as less face-to-face interactions between students and facilitators (Sudiana, Fatah, and Khaerunnisa, 2017).

Some argue than online learning increases students' participations in the class (Saifuddin, 2018) because they are more confident and comfortable in asking or responding questions (Firman and Rahman, 2020). Furthermore, students become more independent in solving problems because they are asked to be more active in searching information related to the course (Firman and Rahman, 2020; Herliandry et al., 2020). Although many support the online learning, some others criticize that online learning needs longer preparation time for the teaching and learning activities, considerably costly (Herliandry et al., 2020), and may result in anxiety due to slow feedbacks given to the students (Pangondian, Paulus, and Nugroho, 2019).

Online learning also provides challenges for both students and teachers, one of which is due to the online learning infrastructure (Firman and Rahman, 2020). This online learning requires good internet access and gadgets (Bustomi, 2020), which are not always available (Dewi, 2020; Khasanah, Pramudibyanto, and Widuroyekti, 2020). Apart from the infrastructure, teachers/lecturers are also shocked as they have to master information and technology skills as online learning involves video conference and other learning media which force the teachers/lecturers to be more creative and adaptive in delivering the course materials (Bustomi, 2020; Djaja, 2016; Herliandry et al., 2020; Sole and Anggraeni, 2018). With the minimum supports from schools or educational institutions, teachers and students are borne by the costs to access the online learning (Abidin, Rumansyah, and Arizona, 2020; Firman and Rahman, 2020; Herliandry et al., 2020). Moreover, students also complain about their difficulties in understanding the course materials and completing the homework due to the communication barriers between the students and the teachers (Bustomi, 2020; Firman and Rahman, 2020; Juliane et al., 2017). To minimize those challenges, teachers may adopt the project-based or problem-based assignments which require the students to search information related to the assigned projects (Abidin, Rumansyah, and Arizona, 2020; Chasanah, Khoiri, and Nuroso, 2016).

Although the learning is conducted through online platforms, the assessments must be able to measure students' performances. Assessments also serves as instruments to check the student's achievements, planned learning outcomes, feedbacks as well as the instructors' monitoring instruments (Born, 2003). Online exams can be set to maximize and fasten the teachers' scoring objectivity (Aripin, Silalahi, and Ulfa, 2020). It is expected that online exams possibly minimize the students' cheating activities. However, without proper planning, those will encourage the students to do more cheating 
activities by creating notes, using gadgets to find the answers, or communicate with the others (Abdullahi and Mansor, 2015; Murdiansyah, Sudarman, and Nurkholis, 2017). The next section discusses the online exam designs to prevent from the students' cheating activities by providing the individualized excel-based exams.

\section{METHODS}

In the final exam of the Intermediate Accounting course, there were seven questions consisting of four conceptual and three problem-based questions to answer. The conceptual questions were set the same for all students. However, each problem was designed individually for each student, both related to the accounting method and/or policy choices as well as the numbers involved in the problems. Hence, an excel spreadsheet was used to automatically generate methods and numbers based on the students' identification number. Excel is an essential feature in accounting education (Beaman, Waldmann, and Krueger, 2005; Chandler and Marriott, 1994) that the accounting lecturers should have sufficient excel skills, especially in designing excel-based exams.

In this higher education institution where the exams were conducted, a student's ID has a 12-digit number, with some differences in the sixth and last four digits. Hence, the starting point to design an individualized exam was using those numbers with some excel functions to generate numbers. From those 12 digits, only five unique digits of each student were utilized instead of the last digit usually used to create a distinctive figure for each student.

Students were first asked to fill 12 digits of their student's IDs in the 12 cells. This ID was used to produce numbers and select the accounting method. To avoid incorrect input of two or more digits in a cell, data validation was set to constrain the number of only from 0 to $9^{1}$. The cells were also shaded with a bright green color to attract the students' attention. Instructions were clearly provided for the students to input 12 digits of their student's IDs in the bright green-shaded cells, while the notification of numbers and methods for each question will be different based on each student's ID (see Figure 1).

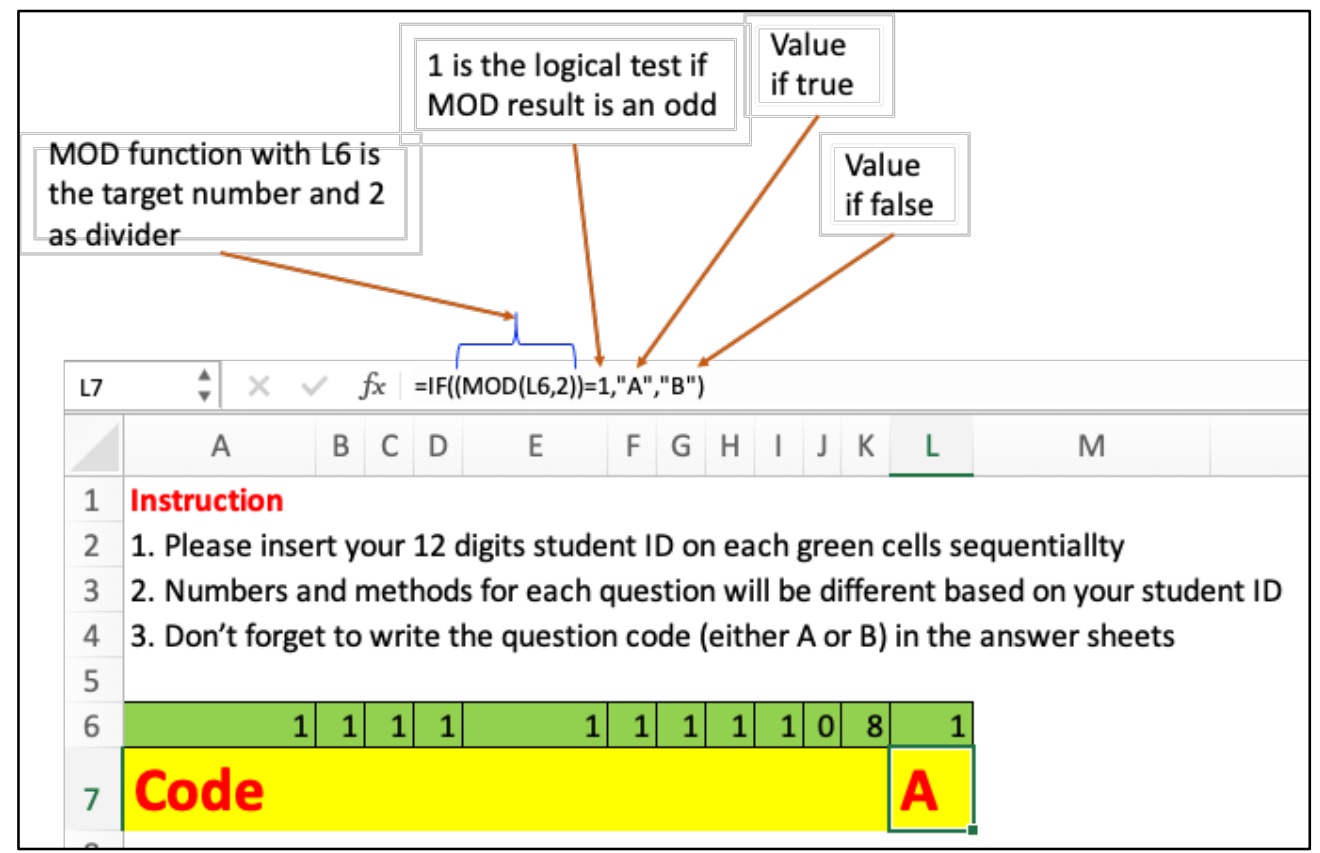

Figure 1. Instructions to complete the cells

\footnotetext{
${ }^{1}$ To do this, click on Excel Ribbon: Data - data validation - whole number - minimum 0 - maximum 9.
} 
Students were then classified into the odd or even group. This classification was to decide the accounting method used in solving the problems. Hence, the Excel's MOD function was used with the last digit of student's IDs as the number and 2 as the divisor ${ }^{2}$. There were two outcomes: 1 and 0 , with 1 represented the odd group (Group A), and 0 represented the even group (Group B). This formula was then combined with the IF function to provide notifications for those students whether belonging to Group A or B (see Figure 1). This group needs to specify the students' answer sheets. For example, students were asked to make journal entries either for the lessee (Group A) or lessor (Group B, see Figure 2). IF function was used to assign which method should be conducted by the students.

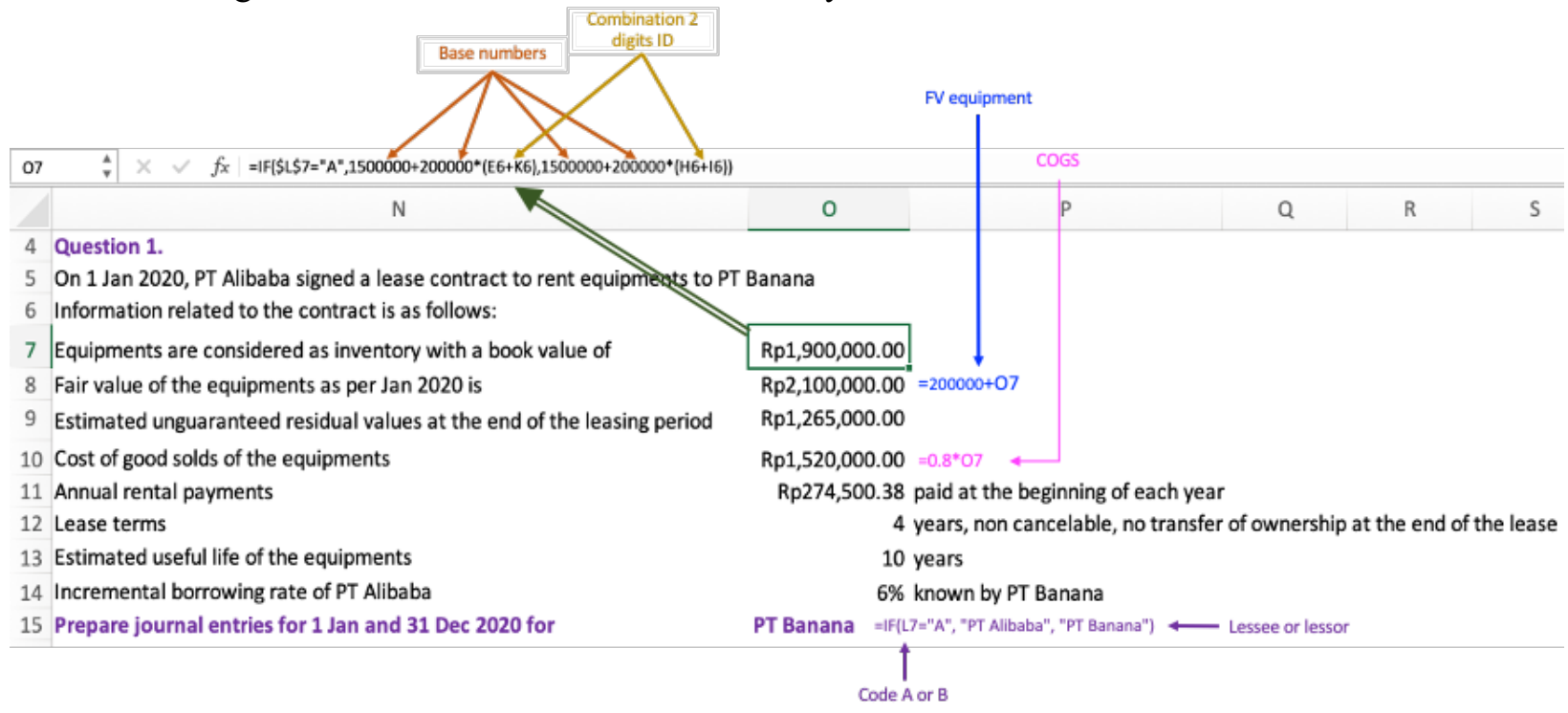

Figure 2. Sample questions and formula

Prior to assigning numbers, a base number was set and then the IF function was used to assign the unique numbers to each problem provided for the exam (see Figure 2). As previously explained, only five numbers are unique to each student $\left(6^{\text {th }}, 9^{\text {th }}, 10\right.$ th, $11^{\text {th }}$ and $\left.12^{\text {th }}\right)$, and then the combination of $6^{\text {th }}$ and $9^{\text {th }}$ with $10^{\text {th }}$ to $12^{\text {th }}$ were used to set figures in the questions. For instance, continue the lease problem. The first value was set for the leased equipment's book value. It was set as a combination of question codes and base numbers, added with the multiplication of student's ID. The second value was set for the equipment's fair value of IDR 200,000 higher than the equipment's book value. Next, the cost of goods sold was set $80 \%$ of the book value.

In this type of problem, the lecturer needs to be careful in determining the lease terms and estimated useful life as the results are in different leasing types; capital lease or operating lease. The next step, the lease terms (in cell O12) were then set by using IF function. The last digit of student's ID (in cell LO) was used to create a different length of lease as follows:

$$
\begin{aligned}
& =\mathrm{IF}(\mathrm{L} 6=1,3, \operatorname{IF}(\mathrm{L} 6=2,4, \operatorname{IF}(\mathrm{L} 6=3,5, \operatorname{IF}(\mathrm{L} 6=4,5, \operatorname{IF}(\mathrm{L} 6=5,5, \operatorname{IF}(\mathrm{L} 6=6,8, \operatorname{IF}(\mathrm{L} 6=7,9, \operatorname{IF}(\mathrm{L} 6=8,10, \operatorname{IF}(\mathrm{L} 6=9,1 \\
& 1,12))))))))
\end{aligned}
$$

After determining the lease terms, the estimated useful life of asset was determined from cell O12:

$$
\begin{aligned}
& =\mathrm{IF}(\mathrm{O} 12=3,9, \operatorname{IF}(\mathrm{O} 12=4,10, \mathrm{IF}(\mathrm{O} 12=5,8, \operatorname{IF}(\mathrm{O} 12=6,7, \mathrm{IF}(\mathrm{O} 12=7,8, \mathrm{IF}(\mathrm{O} 12=8,8, \mathrm{IF}(\mathrm{O} 12=9,11, \mathrm{IF}(\mathrm{O} 12= \\
& 10,12, \mathrm{IF}(\mathrm{O} 12=11,12,12)))))))) \\
& \ldots \ldots \ldots . .(\text { in cell } O 13)
\end{aligned}
$$

\footnotetext{
${ }^{2}$ At the target cells type $=\operatorname{MOD}(\mathrm{L} 6,2)$ with L6 is the cell containing the last digit student's ID.
} 
In determining the incremental borrowing rate, the second last digit used was:

$$
\begin{aligned}
& =\mathrm{IF}(\mathrm{J} 6=1,7 \%, \mathrm{IF}(\mathrm{J} 6=2,6 \%, \operatorname{IF}(\mathrm{J} 6=3,5 \%, \operatorname{IF}(\mathrm{J} 6=4,8 \%, \operatorname{IF}(\mathrm{J} 6=5,9 \%, \operatorname{IF}(\mathrm{J} 6=6,10 \%, \operatorname{IF}(\mathrm{J} 6=7,11 \%, \operatorname{IF}(\mathrm{J} 6=8, \\
& \ldots \%, \operatorname{IF}(\mathrm{J} 6=9,12 \%, 13 \%)))))))
\end{aligned}
$$

Once the lease terms, life of equipment, and borrowing rate were set, the estimated unguaranteed residual value could be calculated by using the following formula:

$$
\begin{aligned}
\text { Residual value } & =\{\text { depreciation rate } \mathrm{x} \text { (useful life }- \text { lease term) }\}+\text { base number } \\
& =\{(\text { book value } / \text { useful life) } \mathrm{x} \text { (useful life }- \text { lease term) }\}+\text { base number }(1)
\end{aligned}
$$

In the excel sheet, the formula was:

$$
=((\mathrm{O} 7 / \mathrm{O} 13) *(\mathrm{O} 13-\mathrm{O} 12))+125000
$$

The last number was the annual rental payment. It was calculated with the following formula:

Annual rental payment $=($ fair value $-\mathrm{PV}$ residual value $) /$ lease term

In the excel sheet, the present value (PV) might be easily calculated that the annual rental payment (cell O11 $)$ became $=(\mathrm{O} 8+\mathrm{PV}(\mathrm{O} 14, \mathrm{O} 12,0, \mathrm{O} 9,1)) / \mathrm{O}_{2} 2^{3}$. Lastly, the sheet was protected, and the formulas were hidden before distributing the exam ${ }^{4}$.

In addition to the creation of exam's questions, the solutions to the problems were also designed in different Excel sheet. This scoring guide was purposively designed to make the exam scoring operate faster. The numbers in problems were connected with the solutions while the point for each correct answer was defined. Once student's ID was input to the solution sheet, the correct answer changed. This method enables the scoring to operate faster, although the students submitted the answers in the form of photo.

\section{Exam Delivery}

The exams were conducted in three classes at the same time and at the same date. The individual exam question was available sequentially in the e-learning (Moodle-based) platform at one specific time. Students could only see the exam questions at the set time. As many students were from rural areas where internet connection is somehow inaccessible and/or limited, the individual exam question is also sequentially sent via WhatsApp Group at the same time with the question appeared through e-learning. WhatsApp has been used as a means of communication in medical schools (Dar et al., 2017; Willemse, 2015), engineering (Nitza and Roman, 2016), and education (Awada, 2016; Hamad, 2017; Mwakapina, Mhandeni, and Nyinondi, 2016; Susilo, 2014). This platform allows the students to have online discussions, while the teachers found it easier to deliver the online tutorials, learning materials, and assignments, including instructions (So, 2016; Susilo, 2014). Hence, it is not surprising that WhatsApp, including WhatsApp group, is very popular in Indonesia, although sometimes the participants send spams and hoaxes (Bouhnik and Deshen, 2014; Cetinkaya, 2017) while teachers should be prepared to spend time outside their normal working hours (Bouhnik and Deshen, 2014).

Each question had different points; a more complex problem had a higher score and took more time to finish. Hence, the time allocation for each question was set differently. Students were given a limited time to answer each problem. This information was sent to the students a week before the exam to have better preparation. Instructions of how to answer the exam questions and how to submit their answers to be marked was sent before the exam date. Since the students' typing speed could not be equalized, the students' laptops or PCs had different technical specifications, and based on the agreement with the students; the answers were paper based; one sheet for one question.

\footnotetext{
${ }^{3}$ The formula to calculate this present value is PV (interest rate, lease term period, annual payment of 0 , guaranteed residual value, and 1 for beginning of the year).

${ }^{4}$ Select all worksheets except for the green cells for the student's ID, right click, choose protection tab and then select locked and hidden. Next, click Tools in the ribbon, protection, and protect sheet. Fill in the passwords to lock the worksheet.
} 
Once the students had completed one problem, they were asked to take a picture of each answer, scanned it, upload it either to the e-learning platform, or send it to the lecturers' WhatsApp numbers. Students were given five minutes after the exam ended to upload their answer sheets. After this upload time ended, the next question was then opened for the students.

These online exams were set to be invigilated. Hence, the students were asked to join the online classrooms via Webex ${ }^{5}$ with mode-on video that the lecturers were able to see what the students did during the exam to prevent from the students' cheating activities. As previously explained, this excel-based exam is already individualized with each student receiving different methods and numbers. Hence, the online surveillance plus individualized-type questions are expected to reduce the cheating opportunities as the answers of each student are different from the others. The students' perceptions and feedbacks regarding to this online, individualized excel-based exam are further discussed in the next section.

\section{RESULTS AND DISCUSSION}

To measure the effectiveness, Qualtrics online survey was conducted to the students participating in this online individualized excel-based final exam after the final scores were announced $(n=80)$. Each questionnaire consisted of 16 questions. Students were questioned related to their genders, final exam scores, 14 questions on the easiness use of this online individualized excel-based final test, and their reflections (Alsadoon, 2017; Deutsch et al., 2012; Hillier, 2015; Özden, Ertürk, and Sanli, 2004), measured with the 5-point Likert scale. The survey was opened for a week, and 76 responses were collected. The students were further classified into high achievers (if the exam mark is more than or equal to 85) and nonhigh achievers (for those less than 85). For data screening, we checked the univariate outliers from the standardized value for each Likert scale item. We found three outlier cases, and these were then removed from the data for further analysis (Hair et al., 2014), resulting in a $91 \%$ response rate. After removing the outliers, a normality test was conducted using skewness and kurtosis, and showed that all the data was normally distributed.

A principle component analysis (PCA) was then conducted on those 14 items with a direct oblimin rotation to classify the questionnaire into several factors and check the construct and discriminant validity. The Kaiser-Meyer-Olkin measure verified the sampling adequacy for the analysis, with $\mathrm{KMO}=0.753$, and all KMO values for individual items were more than the minimum threshold of 0.5 (Field, 2013). Bartlett's test of sphericity with $\chi^{2}(91)=288.803$ and $p<0.001$, indicated that the correlations between items were sufficiently large for PCA. An initial analysis was conducted to obtain the eigenvalues for each data component. Five data components had the eigenvalues of more than one and in combination, explained by $69.56 \%$ of the variance. Table 1 shows the after-rotation loading factor. The items clustered in the same components suggested that component $1,2,3,4$ and 5 respectively represented the easiness, timeliness, self-efficacy, challenge, and integrity concern of the online exam. These factor scores were then used for further analysis.

Table 1. Factor loading for each item

\begin{tabular}{|c|c|c|c|c|c|}
\hline Items & Easiness & $\begin{array}{l}\text { Time } \\
\text { lines }\end{array}$ & $\begin{array}{c}\text { Self- } \\
\text { efficacy }\end{array}$ & Challenge & Integrity \\
\hline Applicable to other courses & .855 & & & & \\
\hline Preferring the online to offline exam & .820 & & & & \\
\hline The system is easy to use & .816 & & & & \\
\hline $\begin{array}{l}\text { Feeling Relax if future exam is conducted } \\
\text { online }\end{array}$ & .767 & & & & \\
\hline Recommending online for future exams & .744 & & & & \\
\hline $\begin{array}{l}\text { Online exams objectively reflect the students' } \\
\text { performance }\end{array}$ & .518 & & & & \\
\hline
\end{tabular}

${ }^{5}$ Webex is an online video conferencing platform. 


\begin{tabular}{|c|c|c|c|c|c|}
\hline Not feeling panic when doing the exams & & 847 & & & \\
\hline Requiring less time finishing the online exams & & 696 & & & \\
\hline believing of having enough competence & & & .693 & & \\
\hline Not ashamed after finishing the exams & & & .649 & & \\
\hline Feeling Proud after finishing the exams & & & .607 & & \\
\hline Online exams are enjoyable challenges & & & & .887 & \\
\hline $\begin{array}{l}\text { Reading on screen adding no difficulties } \\
\text { during the exams }\end{array}$ & & & & .819 & \\
\hline Online exams reduce cheating opportunities & & & & & 995 \\
\hline Eigenvalues & 4.258 & 1.654 & 1.479 & 1.321 & 1.026 \\
\hline$\%$ of variance & 30.411 & 11.814 & 10.567 & 9.437 & 7.331 \\
\hline$\alpha$ & .869 & .568 & .562 & 661 & N/A \\
\hline
\end{tabular}

Based on those classifications, the descriptive statistical data were shown in Table 2. Although all mean scores were greater than 3 , out of 5 , the students relatively agreed that the online exam was technically easy to follow and appropriate to use for the future exams in other courses. In addition, students also felt that in the online exam environment, they believed that they had a higher competence and less panic. Hence, they felt that there was no feasible challenge when reading the questions on the screen instead of on paper. These positive experiences made the students preferred online to offline exam and agreed if the future exams will be conducted via online that they will feel relax. Students also considered that it was harder for them to do cheating activities during the personalized type exams were conducted. Hence, they believed that an online exam objectively reflected their performance.

Table 2. Descriptive statistics

\begin{tabular}{lllll}
\hline Items & Min & Max & Mean & Stdev \\
\hline Easiness & & & & \\
$\quad$ Applicable for other courses & 2 & 5 & 3.66 & 0.866 \\
$\quad$ Preferring online to offline exams & 1 & 5 & 3.39 & 1.054 \\
$\quad$ The system is easy to use & 2 & 5 & 3.71 & 0.769 \\
$\quad$ Feeling Relax if future exam is conducted online & 2 & 5 & 3.46 & 0.846 \\
$\quad$ Recommending online for future exams & 2 & 5 & 3.46 & 0.846 \\
$\quad$ Online exams objectively reflect the students' performance & 2 & 5 & 3.24 & 0.875 \\
Timeliness & & & & \\
$\quad$ Not panic when doing the exams & 2 & 5 & 3.77 & 0.837 \\
$\quad$ Need less time finishing the online exams & 1 & 5 & 3.32 & 0.883 \\
Self-efficacy & 2 & 5 & 3.83 & 0.747 \\
$\quad$ believing of having enough competence & 2 & 5 & 3.65 & 0.819 \\
$\quad$ Not ashamed when finishing the exams & 2 & 5 & 3.34 & 0.899 \\
$\quad$ Proud after finishing the exams & & & & \\
Challenge & 1 & 5 & 3.30 & 0.922 \\
$\quad$ Online exams are enjoyable challenges & 2 & 5 & 3.47 & 0.863 \\
$\quad$ Reading on screen add no difficulties during the exams & & & & \\
Integrity & 1 & 5 & 3.35 & 0.952 \\
\hline Online exams reduce cheating opportunities & & &
\end{tabular}

Independent sample t-tests were then conducted to check the differences between gender and high achiever students based on five factors. On average, female students expressed the decreasing cheating opportunities $(\mathrm{M}=0.159, \mathrm{SE}=0.963)$ more than male students $(\mathrm{M}=-0.505, \mathrm{SE}=0.975)$. This difference ${ }^{6}$ was significant with $\mathrm{t}(65)=-25.399$ and $\mathrm{p}<0.05$; representing a medium-sized effect with $\mathrm{r}=0.29$. This finding implied that male students perceived that cheating opportunities during the online exams were higher than the female students did. This was probably caused by the female students' learning efforts were

\footnotetext{
${ }^{6}$ For robustness check, a non-parametric test was conducted and showed similar findings (Mann Whitney $U=246 ; p=0.017$ ). There was no significant different between the high and non-high achiever students.
} 
bigger than male students' (Dodeen, 2012), since male students perceived that cheating was more morally acceptable (Smyth and Davis, 2003). Although academic cheating activities happened more in offline classes than online environments (Watson, George, and Sottile, 2010), educators should take extra precautions when designing online tests, such as by designing subjective exams (essay questions) than objective measures (multiple choice questions).

\section{CONCLUSION}

This study aims at explaining the online exam methods in accounting subjects during the outbreak of Covid-19 pandemic. The exams are uniquely designed for each student to reduce cheating opportunities and relatively ease the scoring. This automatic scoring may improve the scoring process credibility scoring and minimize the calculation errors. From the students' feedbacks, it is shown that online exam is not considered as a burden and believed reducing the cheating opportunities during the exam. This personalized exam may be further developed in class practices where the students may directly answer the questions presented in the excel sheets with auto scoring feature. This may also be developed using the automatic feedbacks provided in the students' worksheets. Meanwhile, the problems arising in such individualized creating processes are related to the longer period of time, yet those considerably reduce the scoring workloads.

\section{REFERENCES}

Abdullahi, Rabi'u, and Noorhayati Mansor. 2015. "Fraud Triangle Theory and Fraud Diamond Theory. Understanding the Convergent and Divergent for Future Research." International Journal of Academic Research in Accounting, Finance and Management Sciences 5(4): 38-45.

Abidin, Zainal, Rumansyah, and Kurniawan Arizona. 2020. "Pembelajaran Online Berbasis Proyek Salah Satu Solusi Kegiatan Belajar Mengajar di Tengah Pandemi Covid-19." Jurnal Ilmiah Profesi Pendidikan 5(1): 64-70.

Alsadoon, Hamadah. 2017. "Students' Perceptions of E-Assessment at Saudi Electronic University." TOJET: The Turkish Online Journal of Educational Technology 16(1): 147-53.

Aripin, Soeb, Natalia Silalahi, and Kurnia Ulfa. 2020. "Pengenalan Dan Penggunaan Website Ujian Online Sebagai Media Pembelajaran Pada Siswa/Siswi SMA Negeri 1 STM Hilir." Jurnal Abdimas Budidarma 1(1): 19-22. https://tryout.pendidikan.id.

Ashworth, P., P. Bannister, and P Thorne. 1997. "Guilty in Whose Eyes? University Students' Perceptions of Cheating and Plagiarism in Academic Work and Assessment." Studies in Higher Education 22(2): 187-203.

Awada, Ghada. 2016. "Effect of WhatsApp on Critique Writing Proficiency and Perceptions toward Learning." Cogent Education 3(1): 1-25.

Beaman, I., E Waldmann, and P. Krueger. 2005. "The Impact of Training in Financial Modelling Principles on the Incidence of Spreadsheet Errors." Accounting Education: An International Journal 14(2): 199-212.

Bento, Regina, and Cindy Schuster. 2003. "Participation: The Online Challenge." In Web-Based Education: Learning from Experience, ed. Anil K. Aggarwal. Hershey, UK: IRM Press, 156-64.

Bertheussen, Bernt Arne. 2014. "Power to Business Professors: Automatic Grading of Problem-Solving Tasks in a Spreadsheet." Journal of Accounting Education 32(1): 76-87.

Blayney, P., and M Freeman. 2008. "Individualised Interactive Formative Assessments to Promote Independent Learning." Journal of Accounting Education 26(3): 155-65. 
Born, Apiwan D. 2003. "Web-Based Student Assessment." In Web-Based Education: Learning from Experience, ed. Anil K. Aggarwal. Hershey, UK: IRM Press, 165-88.

Bouhnik, D., and M. Deshen. 2014. "WhatsApp Goes to School: Mobile Instant Messaging between Teachers and Students." Journal of Information Technology Education: Research 13.

Bustomi, Ahmad. 2020. "Implikasi Covid 19 Terhadap Pembelajaran Di Perguruan Tinggi." Jurnal Tawadhu 4(1): 1007-17.

Cetinkaya, Levent. 2017. "The Impact of Whatsapp Use on Success in Education Process." International Review of Research in Open and Distributed Learning 18(7).

Chandler, R., and N Marriott. 1994. "Different Approaches to the Use of Spreadsheet Models in Teaching Management Accounting." Accounting Education: an international journal 3(2): 133-55.

Chasanah, Angga Risnaini Uswatun, Nur Khoiri, and Harto Nuroso. 2016. "Efektivitas Model Project Based Learning Terhadap Keterampilan Proses Sains Dan Kemampuan Berpikir Kreatif Siswa Pada Pokok Bahasan Kalor Kelas X SMAN 1 Wonosegoro Tahun Pelajaran 2014/2015." Jurnal Penelitian Pembelajaran Fisika 7(1): 19-24.

Dar, Qudsia Anwar et al., 2017. "Use of Social Media Tool 'Whatsapp' in Medical Education.” ANNALS 23(1): 39-42.

Deutsch, Tobias, Kristin Herrmann, Thomas Frese, and Hagen Sandholzer. 2012. "Implementing Computer-Based Assessment - A Web-Based Mock Examination Changes Attitudes." Computers and Education 58: 1068-75.

Dewi, Wahyu Aji Fatma. 2020. "Dampak Covid-19 Terhadap Implementasi Pembelajaran Daring Di Sekolah Dasar." Edukatif: Jurnal Ilmu Pendidikan 2(1): 55-61.

Djaja, Sutrisno. 2016. "Harapan Dan Tantangan Guru Pembelajar Moda Daring." Jurnal Pendidikan Ekonomi 10(2).

Dodeen, Hamzeh M. 2012. "Undergraduate Student Cheating in Exams." Damascus University Journal 28(1): 37-54.

Doran, J., M. Healy, M. McCutcheon, and S O'Callaghan. 2011. “Adapting Case-Based Teaching to Large Class Settings: An Action Research Approach." Accounting: An International Journal 20(3): 24563.

Evans, C. 2013. "Making Sense of Assessment Feedback in Higher Education." Review of Educational Research 83(1): 70-120.

Field, A. 2013. Discovering Statistics Using IBM SPSS Statistics. Sage.

Firman, and Sari Rahayu Rahman. 2020. "Pembelajaran Online di Tengah Pandemi Covid-19." Indonesian Journal of Educational Science (IJES) 2(2): 81-89.

Gikandi, J. W., D. Morrow, and N. E Davis. 2011. "Online Formative Assessment in Higher Education: A Review of the Literature." Computers \& Education 57: 2333-51.

Hair, Joseph F. Jr., William C. Black, Barry J. Babin, and Rolphe E. Anderson. 2014. Multivariate Data Analysis. New York: Prentice Hall.

Hamad, Mona M. 2017. "Using WhatsApp to Enhance Students' Learning of English Language 'Experience to Share." Higher Education Studies 7(4): 74.

Harmon, Oskar R, James Lambrinos, and Judy Buffolino. 2010. "Assessment Design and Cheating Risk in Online Instruction." Online Journal of Distance Learning Administration 13(3). https://www2.westga.edu/ distance/ojdla/Fall133/harmon_lambrinos_buffolino133.html. 
Herliandry, Luh Devi, Nurhasanah, Maria Enjelina Suban, and Kuswanto Heru. 2020. "Pembelajaran Pada Masa Pandemi Covid-19." Jurnal Teknologi Pendidikan 22(1): 65-70. http://journal.unj.ac.id/unj/index.php/jtp.

Hillier, Mathew. 2015. "E-Exams with Student Owned Devices: Student Voices." In Proceedings of the International Mobile Learning Festival 2015: Mobile Learning, MOOCs and 21st Century Learning, , 582-608.

Juliane, Christina, Arry A. Arman, Husni S. Sastramihardja, and Iping Supriana. 2017. "Digital Teaching Learning for Digital Native: Tantangan Dan Peluang." Jurnal Ilmiah Rekayasa dan Manajemen Sistem Informasi 3(2): 29-35.

Khasanah, Dian Ratu Ayu Uswatun, Hascaryo Pramudibyanto, and Barokah Widuroyekti. 2020. "Pendidikan Dalam Masa Pandemi Covid-19." Jurnal Sinestesia 10(1): 41-48. https://sinestesia.pustaka.my.id/journal/article/view/44.

King, Chula G, Roger W Guyette, and Chris Piotrowski. 2009. "Online Exams and Cheating: An Empirical Analysis of Business Students' Views.” The Journal of Educators Online 6(1).

Marriott, P., and A. Lau. 2008. "The Use of On-Line Summative Assessment in an Undergraduate Financial Accounting Course." Journal of Accounting Education 26(2): 73-90.

Murdiansyah, Isnan, Made Sudarman, and Nurkholis. 2017. "Pengaruh Dimensi Fraud Diamond Terhadap Perilaku Kecurangan Akademik.” Jurnal Akuntansi Aktual 4(2): 121-33.

Mwakapina, Job W., Abdulkarim S. Mhandeni, and Onesmo S. Nyinondi. 2016. "WhatsApp Mobile Tool in Second Language Learning: Opportunities, Potentials and Challenges in Higher Education Settings in Tanzania." International Journal of English Language Education 4(2): 70-90.

Nitza, Davidivitch, and Yavich Roman. 2016. "WhatsApp Messaging: Achievements and Success in Academia." International Journal of Higher Education 5(4): 256-61.

Nnadi, M. A. 2003. "Effective Measures of Curbing Malpractices in Accounting Examinations in Nigeria." Journal of Business Education 3(2): 35-42.

Nnadi, Matthias, and Mike Rosser. 2014. "The 'Individualised Accounting Questions' Technique: Using Excel to Generate Quantitative Exercises for Large Classes with Unique Individual Answers." Accounting Education: An International Journal 23(3): 193-202.

Özden, M Yasar, Ismail Ertürk, and Refik Sanli. 2004. "Students' Perceptions of Online Assessment: A Case Study." Journal of Distance Education 19(2): 77-92.

Pangondian, Roman Andrianto, Santosa Insap Paulus, and Eko Nugroho. 2019. "Faktor - Faktor Yang Mempengaruhi Kesuksesan Pembelajaran Daring Dalam Revolusi Industri 4.0." In Seminar Nasional Teknologi Komputer \& Sains (SAINTEKS), 56-60. https://seminar-id.com/semnassainteks2019.html.

Rogers, Camille F. 2006. "Faculty Perceptions about E-Cheating during Online Testing." In CCSC: Southeastern Conference, , 206-12.

Saifuddin, Much. Fuad. 2018. "E-Learning Dalam Persepsi Mahasiswa.” Jurnal VARIDIKA 29(2): 102-9.

Sindre, G., and A. Vegendla. 2015. "E-Exams versus Paper Exams: A Comparative Analysis of CheatingRelated Security Threats and Countermeasures." In the Norwegian Information Security Conference (NISK).

Smyth, M Lnnette, and James R Davis. 2003. "An Examination of Student Cheating in the Two-Year." Community College Review 31(1): 17-32. 
So, Simon. 2016. "Mobile Instant Messaging Support for Teaching and Learning in Higher Education." Internet and Higher Education 31: 32-42.

Sole, Ferdinandus Bele, and Desak Made Anggraeni. 2018. "Inovasi Pembelajaran Elektronik Dan Tantangan Guru Abad 21." Jurnal Penelitian dan Pengkajian Ilmu Pendidikan: E-Saintika 2(1): 1018

Sudiana, Ria, Abdul Fatah, and Dan Etika Khaerunnisa. 2017. "Kemandirian Belajar Mahasiswa Melalui Pembelajaran Berbasis Virtual Class." Jurnal Penelitian Dan Pembelajaran Matematika 10(1): 74 80 .

Susilo, Adhi. 2014. "Exploring Facebook and Whatsapp As Supporting Social Network Applications for English Learning In Higher Education.” Professional Development in Educational: 10-24.

Watson, George, and James Sottile. 2010. "Cheating in the Digital Age: Do Students Cheat More in Online Courses?" Online Journal of Distance Learning Administration 13(1).

Willemse, Juliana J. 2015. "Undergraduate Nurses Reflections on Whatsapp Use in Improving Primary Health Care Education." Curations 38(2): 1-7. 